\title{
ОЦІНКА ЯКОСТІ ЖИТТЯ ТА ПСИХОЕМОЦІЙНОГО СТАТУСУ У ХВОРИХ НА ХРОНІЧНИЙ ПАНКРЕАТИТ
}

\author{
๑о. Є. Кітура, М. М. Потяженко, Г. В. Невойт, Н. Л. Соколюк, Є. О. Величко \\ Навчально-науковий інститут післядипломної освіти ВДнзу «Українська медична стоматологічна \\ академія», м. Полтава
}

PЕзЮМЕ. В зв'язку із важливістю і недостатньою кількістю досліджень, що відображають рівень психоемоційного стану хворих на хронічний панкреатит, метою роботи було оцінити якість життя та ступінь тривожності у хворих на ХП. У 68 хворих на ХП за візуальною аналоговою шкалою оцінені інтенсивність больового синдрому, за опитувальником GSRS - якість життя, за опитувальником Ч. Д. Спілбергера - Ю. Л. Ханіна - наявність тривожних розладів. Встановлено, що ухворих на ХП наявний вищий рівень реактивноїта особистісноїтривожності, ніж у групі контролю, відмічаються погіршення якості життя, суттєві зміни в психоемоційному статусі. Погіршення якості життя має прямий зв'язок з виразністю больового, діарейного синдромів.

КлючОВІ СЛОВА: хронічний панкреатит; психоемоційний статус; якість життя.

Вступ. Значна поширеність та захворюваність на хронічний панкреатит (ХП) як в Україні, так і в світі, зумовлюють актуальність питань підвищення ефективності лікування хворих з вказаною патологією. Для персоніфікованого підходу в практиці сімейного лікаря важливо враховувати психоемоційний статус пацієнта. Показник якості життя (ЯЖ) може забезпечувати індивідуальний моніторинг стану хворого з оцінкою ранніх та віддалених результатів лікування, розробку прогностичних моделей перебігу та наслідків захворювання, являючи собою новий інтегральний підхід до комплексної оцінки стану здоров'я хворого за сукупністю об'єктивних медичних даних і суб'єктивної оцінки самого пацієнта [1-5]. Враховуючи, що результати подальшого вивчення ЯЖ та психологічних особливостей пацієнтів з ХП можуть сприяти підвищенню комплаєнсу між хворим і сімейним лікарем щодо дотримання дієтичних рекомендацій, модифікації способу життя, виконанні вказівок медикаментозного лікування та підвищенню ефективності лікування, метою роботи було оцінити ЯЖ та ступінь виразності тривожності у хворих на ХП.

Матеріал і методи дослідження. Обстежено 68 хворих, з них 36 жінок (середній вік $(56,9 \pm 7,4)$ роки, тривалість захворювання - $(9,5 \pm 4,9)$ роки)) з встановленим діагнозом ХП згідно з наказом МОЗ України від 10.09.2014 № 638. Оцінювали інтенсивність 6ольового синдрому за візуальною аналоговою шкалою (ВАШ) [6], ЯЖ - за допомогою спеціалізованого опитувальника гастроентерологічного хворого GSRS (Gastrointestinal Simptom Rating Scale) [3, 5], наявність тривожних розладів - за опитувальником Ч. Д. Спілбергера - Ю. Л. Ханіна [2]. Контрольну групу склали 30 здорових осіб, рандомізованих за віком та статтю. Статистичну обробку одержаних результатів здійснювали за допомогою дисперсійного аналізу з використанням пакетів ліцензійних програм Microsoft Office 2003, Microsoft Excel Stadia 6.1/prof i Statistica.
Результати й обговорення. При аналізі інтенсивності больового синдрому у хворих на ХП за шкалою ВАШ виділено чотири клінічні групи: I група - $10(14,7 \%)$ хворих які не відмічали болю, II група - $12(17,6 \%)$ хворих, які відмічали слабкий біль, III група - 36 (52,9 \%) пацієнтів, що оцінювали біль як помірний, та IV клінічна група - $10(14,7 \%)$ хворих, які відмічали сильний абдомінальний біль.

Аналізуючи результати визначення ЯЖ за опитувальником GSRS, у хворих на ХП, порівняно 3 контрольною групою, відмічено достовірне збільшення показників за трьома з п'яти шкал: абдомінальний біль, диспепсичний та діарейний синдроми. ЯЖ у хворих на ХП за шкалою «Абдомінальний біль» склала $(10,2 \pm 3,6)$ бали, в контрольній групі - $(2,4 \pm 0,8)$ бали $(p<0,05)$, за шкалою «Диспептичний синдром» - $(20,4 \pm 3,2)$ бали в основній групі та $(7,0 \pm 1,2)$ бали в групі контролю $(p<0,01)$, за шкалою "Діарейний синдром" відповідно $(15,3 \pm 3,4)$ бали та $(5,1 \pm 1,3)$ бали $(p<0,01)$.

При аналізі Яж у кожній клінічній групі відмічено достовірне погіршення Яж в III та IV групах, обумовлене виразністю больового синдрому, а в I та II групах - діарейного синдрому. При оцінці за шкалою «Диспептиний синдром» достовірних відмінностей не виявлено (табл. 1).

У хворих на ХП виявлено достовірно вищий рівень реактивної та особистісної тривожності, ніж в осіб контрольної групи. Так, рівень РТ у паці$\epsilon$ ттів з ХП становив $(3,25 \pm 0,67)$ бали, в контрольній групі - $(1,7 \pm 0,24)$ бали $(p<0,05)$, рівень ОТ у хворих на ХП склав $(2,95 \pm 0,29)$ бали, в контрольній групі - $(1,65 \pm 0,12)$ бали $(p<0,001)$. Як видно 3 наведених даних, у хворих із патологією підшлункової залози наявний високий рівень як реактивної, так і особистісної тривожності. Це можна пояснити тим, що особистісна тривожність $\epsilon$ фактором, який полегшує виникнення реакції тривоги, i тому вони тісно взаємозв'язані між собою [11]. 
Огляди літератури, оригінальні дослідження, погляд на проблему

Таблиця 1. Оцінка якості життя хворих на хронічний панкреатит

\begin{tabular}{|l|c|c|c|c|c|}
\hline \multirow{2}{*}{$\begin{array}{c}\text { Клінічна група за } \\
\text { шкалою ВАш }\end{array}$} & \multicolumn{5}{|c|}{ Якість життя за опитувальником GSRS, бали } \\
\cline { 2 - 6 } & $\begin{array}{c}\text { абдомінальний } \\
\text { біль }\end{array}$ & $\begin{array}{c}\text { рефлюкс- } \\
\text { синдром }\end{array}$ & $\begin{array}{c}\text { діарейний } \\
\text { синдром }\end{array}$ & $\begin{array}{c}\text { диспептичний } \\
\text { синдром }\end{array}$ & $\begin{array}{c}\text { обстипаційний } \\
\text { синдром }\end{array}$ \\
\hline $\begin{array}{l}\text { I група } \\
\text { n=10 }\end{array}$ & $5,9 \pm 1,0$ & $10,9 \pm 0,9$ & $19,6 \pm 1,0$ & $23,6 \pm 2,4$ & $8,8 \pm 0,6$ \\
\hline $\begin{array}{l}\text { II група } \\
\text { n=12 }\end{array}$ & $8,9 \pm 1,2$ & $9,8 \pm 1,0$ & $17,9 \pm 1,4$ & $21,4 \pm 2,6$ & $10,4 \pm 0,8$ \\
\hline $\begin{array}{l}\text { III група } \\
\text { n=36 }\end{array}$ & $12,6 \pm 0,8^{* * *}$ & $10,8 \pm 1,2$ & $12,8 \pm 1,6 * * * \wedge$ & $19,0 \pm 1,9$ & $9,8 \pm 1,0$ \\
\hline $\begin{array}{l}\text { IV група } \\
n=10\end{array}$ & $13,4 \pm 0,6^{* * *}$ & $9,6 \pm 0,8$ & $10,9 \pm 1,3^{* * * \wedge \wedge}$ & $17,6 \pm 2,0$ & $10,2 \pm 0,9$ \\
\hline
\end{tabular}

Примітки: ***-р<0,001 в порівнянні з І клінічною групою;

^- $p<0,05 ;{ }^{\wedge \wedge}$ - $p<0,01$ в порівнянні з ІІ клінічною групою.

Відмічено дуже високий рівень РТ у пацієнтів IV групи - $(3,6 \pm 0,32)$ бали, високий рівень РТ в I та III групах - $(3,3 \pm 0,3)$ бали та $(3,4 \pm 0,3)$ бали відповідно, в II групі - середній рівень РТ - $(2,72 \pm 0,28)$ бали. Це можна пояснити тим, що у пацієнтів III та IV груп більш виражений больовий синдром, а I групи діарейний синдром. У I та IV групах спостерігали високий рівень ОТ - $(3,0 \pm 0,27)$ бали та $(3,3 \pm 0,24)$ бали, у пацієнтів II та III груп відмічено середній рівень ОТ- $(2,6 \pm 0,29)$ балита $(2,9 \pm 0,25)$ бали. ОТ підвищує вірогідність появи тривожних розладів в ситуаціях, що потребують оцінки компетентності та можуть бути сприйняті як загрозливі. Проведені раніше дослідження дозволяють припустити, що по мірі прогресування захворювання ОТ перетворюється на безпосередній фактор поси- лення патологічних порушень, тобто формується жорсткий стереотип реагування на психоемоційне навантаження, що не характерно для здорових oci6 $[4,5,7]$.

Висновки. Захворювання на ХП зумовлює суттєві зміни у психоемоційному статусі хворих у вигляді підвищення рівня особистісної та реактивної тривожності та погіршення ЯЖ. Погіршення ЯЖ прямо пов'язано з больовим, диспепсичним, діарейним синдромами і зумовлює високу РТ у хворих на ХП.

Перспективи подальших досліджень. Подальше вивчення психоемоційного статусу у хворих наХПдозволить відпрацювати алгоритми комплексних фармакотерапевтичних підходів і персоніфіковані підходи в практиці сімейного лікаря.

\section{ЛІТЕРАТУРА}

1. Данилов Д. С. Комплаенс в медицине и методы его оптимизации (клинические, психологические и психотерапевтические аспекты) / Д. С. Данилов // Психиатрия и психофармакотерапия им. П. Б. Ганнушкина. - 2008. - № 1. - С. 13-20.

2. Исследование тревожности (Ч. Д. Спилбергер, адаптация Ю. Л. Ханин)/ Диагностика эмоциональнонравственного развития ; ред. и сост. И. Б. Дерманова. - СПб., 2002. - С. 124-126.

3. Качество жизни больных хроническим гепатитом В старше 50 лет / Л. М. Киселева, Л. В. Ильмухина, М. А. Визе-Хрипунова, С. М. Шаршова // Клиническая медицина. - 2009. - № 3. - С. 37-45.

4. Листишенкова Ю. В. Клинико-прогностические аспекты качества жизни и приверженности к лечению у больных хроническим билиарнозависимым панкреати- том [Текст]: дис. на соискание ученой степени канд. мед. наук / Ю. В. Листишенкова. - Саратов, 2010. - 135 с.

5. Неронов В. А. Исследование качества жизни у больных вирусными гепатитами / В. А. Неронов // Курский научно-практический вестник «Человек и его здоровье». - 2009. - № 3.- С. 111-121.

6. Перминов А. Б. Использование визуальноаналоговой шкалы для оценки тяжести состояния пациентов с острым гнойным риносинуситом / А. Б. Перминов // Медицинский журнал : ежеквартальный рецензируемый научно-практический журнал. - 2015. - № 3. - С. 99-102.

7. Харькина Д. Н. Тревожно-депрессивные расстройства у больных хроническим панкреатитом / Д. Н. Харькина, В. И. Мордасова, О. Ю. Ширяев // Журн. теоретич. и практич. мед. - 2005. - № 3 (1). - С. 108-109.

\section{REFERENCES}

1. Danilov, D.S. (2008). Komplaens v meditsine i metody ego optimizatsii klinicheskie, psikhologicheskie i psikhoterapevticheskie aspekty [Compliance in medicine and method of its optimization (clinical, psychological and 
Огляди літератури, оригінальні дослідження, погляд на проблему

psychotherapeuticaspects]. Psikhiatriyaipsikhofarmakoterapiya im. P.B. Gannushkina - Psychiatry and psychopharmacotherapy by P. B. Gannushkina, 1, 13-20 [in Russian].

2. Dermanova, I.B. (2002). Issledovanie trevozhnosti (Ch. D. Spilberger, adaptatsiya Yu. L. Hanin) / Diagnostika emotsionalnonravstvennogo razvitiya [Investigation of anxiety (Ch.D. Spielberger, adaptation by Yu.L. Khanin) / Diagnosis of emotional and moral development]. Saint Petersburg [in Russian].

3. Kiseleva, L.M., Ilmuhina, L.V., Vize-Khripunova, M.A., \& Sharshova S.M. (2009). Kachestvo zhyznibolnykh khronicheskim gepatitom B starshe 50 let [Quality of life of patients with chronic hepatitis B older than 50 years]. Klinicheskaya meditsina - Clinical Medicine, 3, 37-45 [in Russian].

4. Listishenkova,Yu.V. (2010) Klinikoprognosticheskieaspektykachestvazhizniipriverzhennosti k lecheniyu u bolnykh khronicheskim biliarnozavisimyim pankreatitom [Clinical prognostic aspects of quality of life and adherence to treatment in patients with chronic biliary-dependent pancreatitis]. Candidate's thesis. Saratov [in Russian].
5. Neronov, V.A. (2009). Issledovanie kachestva zhyzni u bolnykh virusnymi gepatitami [Investigation of the quality of life in patients with viral hepatitis]. Kurskiy nauchno-prakticheskiy vestnik "Chelovek $i$ ego zdorove" - Kursk Scientific and Practical Journal "The Man and His Health", 3, 111-121 [in Russian].

6. Perminov, A.B. (2015). Ispolzovaniye vizualnoanalogovoyshkalydlya otsenkytyazhestisostoyaniya patsyyentov s ostrym gnoynym rinosinusitom [Using a visual analogue scale to assess the severity of the condition of patients with acute purulent rhinosinusitis]. Meditsinskiy zhurnal: ezhekvartalnyi retsenziruemyy nauchno-prakticheskiy zhurnal - Medical Journal: Quarterly Peer-reviewed Scientific and Practical Journal, 3, 99-102 [in Russian].

7. Kharkina, D.N., Mordasova V.I., \& Shiryaev O.Yu. (2005). Trevozhno-depressivnye rasstroystva u bolnykh khronicheskim pankreatitom [Anxiety-depressive disorders in patients with chronic pancreatitis]. Zhurnal teoreticheskaya $i$ prakticheskaya meditsina - Journal of Theoretical and Practical Medicine, 3 (1), 108-109 [in Russian].

\title{
ОЦЕНКА КАЧЕСТВА ЖИЗНИ И ПСИХОЭМОЦИОНАЛЬНОГО СТАТУСА БОЛЬНЫХ ХРОНИЧЕСКИМ ПАНКРЕАТИТОМ
}

๑О. Е. Китура, М. М. Потяженко, Г. В. Невойт, Н. Л. Соколюк, Е. О. Величко

Учебно-научный институт последипломного образования ВДнзу «Украинская медицинская стоматологическая академия», г. Полтава

РЕЗЮМЕ. В связи с важностью и недостаточным количеством исследований, отображающих уровень психоэмоционального состояния больных хроническим панкреатитом, целью работы было оценить качество жизни и степень тревожности больных хроническим панкреатитом. У 68 больных хроническим панкреатитом по визуальной аналоговой шкале оценены интенсивность болевого синдрома, по вопроснику GSRS - качество жизни, по вопроснику Ч. Д. Спилбергера - Ю. Л. Ханина - наличие тревожных расстройств. Установлено, что у больных хроническим панкреатитом уровень реактивной и личностной тревожности выше, чем в группе контроля, отмечены ухудшение качества жизни, существенные изменения в психоэмоциональном статусе. Ухудшение качества жизни имеет прямую связь с выраженностью болевого, диарейного синдромов.

КЛЮчЕВЫЕ СЛОВА: хронический панкреатит; психоэмоциональный статус; качество жизни.

\section{EVALUATION OF QUALITY OF LIFE AND PSYCHOEMOTIONAL STATUS IN PATIENTS WITH CHRONIC PANCREATITIS}

\author{
@O. Ye. Kitura, M. M. Potjagenko, H. V. Nevoit, N. L. Sokoluk, Ye. O. Velychko \\ Educational and Scientific Institute of Postgraduate Education of the Higher State Educational Establishment \\ of Ukraine «Ukrainian Stomatological Medical Academy», Poltava
}

SUMMARY. Researches of a mental and emotional condition of patients with chronic pancreatitis are important. Their quantity is poor. Quality of life and degree of uneasiness in patients with chronic pancreatitis was to estimate the purpose of work. In 68 patients with chronic pancreatitis we estimated on a visual analog scale - intensity of a pain syndrome, according to the questionnaire of GSRS - quality of life, according to Ch. D. Spilberger - Yu. L. Khanin questionnaire - existence of alarming frustration. It is established that in patients with chronic pancreatitis we noted a high level of jet and personal uneasiness, than in group of monitoring, deterioration of life, essential changes in the psychoemotional status. Deterioration of their life has a feed forward with expressiveness of painful, diarrheal syndromes.

KEY WORDS: chronic pancreatitis; psychoemotional status; quality of life. 